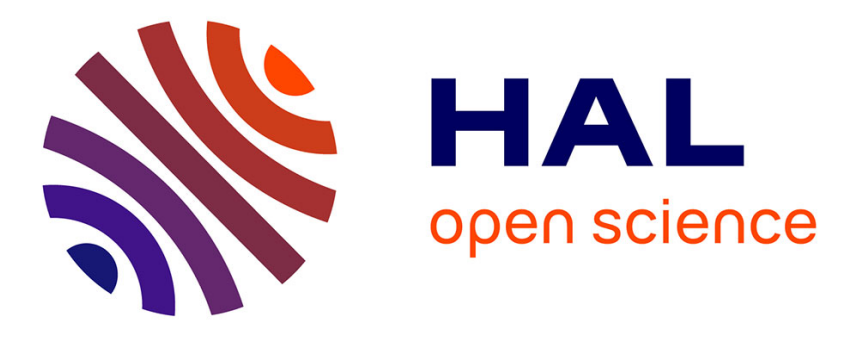

\title{
PENSSART, a new Monte Carlo system for quality control in radiotherapy
}

\author{
Cindy Le Loirec, Juan-Carlos García Hernández, G. Bonniaud, L. Guérin, A. \\ Batalla, Bénédicte Poumarède, Delphine Lazaro-Ponthus
}

\section{To cite this version:}

Cindy Le Loirec, Juan-Carlos García Hernández, G. Bonniaud, L. Guérin, A. Batalla, et al.. PENSSART, a new Monte Carlo system for quality control in radiotherapy. SNA + MC 2013 Joint International Conference on Supercomputing in Nuclear Applications + Monte Carlo, Oct 2013, Paris, France. EDP Sciences, 05306, 2014, 10.1051/snamc/201405306 . cea-01830830

\section{HAL Id: cea-01830830 https: / hal-cea.archives-ouvertes.fr/cea-01830830}

Submitted on 28 Apr 2020

HAL is a multi-disciplinary open access archive for the deposit and dissemination of scientific research documents, whether they are published or not. The documents may come from teaching and research institutions in France or abroad, or from public or private research centers.
L'archive ouverte pluridisciplinaire HAL, est destinée au dépôt et à la diffusion de documents scientifiques de niveau recherche, publiés ou non, émanant des établissements d'enseignement et de recherche français ou étrangers, des laboratoires publics ou privés. 
PENSSART, A NEW MONTE CARLO SYSTEM FOR QUALITY CONTROL IN RADIOTHERAPY

\author{
C. Le Loirec¹, J. C. Garcia-Hernandez¹, G. Bonniaud², L. Guérin³ ${ }^{3}$ A. Batalla³, B. Poumarède ${ }^{1}$ and D. Lazaro ${ }^{1}$
}

cindy.le-loirec@cea.fr

CEA, LIST, Laboratoire Modélisation, Simulation et Systèmes, F-91191, Gif-sur-Yvette, France

Centre de Médecine Nucléaire du Morbihan, Centre d'Oncologie Saint-Yves, 56000 Vannes, France

Centre de Lutte Contre le Cancer François Baclesse, Caen, FRANCE

\title{
Objectives
}

Radiotherapy modalities are now more and more complex and accurate dose calculations are essential for treatment planning. However, in presence of small field sizes and light densities, commercial treatment planning systems (TPS) often fail to predict accurate dose distribution. In this aim, we have developed a new Monte Carlo system called PENSSART for PENELOPE Simulation for the Safety in Radiotherapy.

\section{PENSSART system}

The PENSSART system is divided into three modules.

The dose calculation module is the core of the PENSSART system as it includes the $\mathrm{MC}$ dose computation engine itself which is based on PENELOPE. This module was designed to perform $M C$ dose calculations within voxelized geometries and needs as input data a description of the patient anatomy or phantom geometry as well as a description of the radiation source.

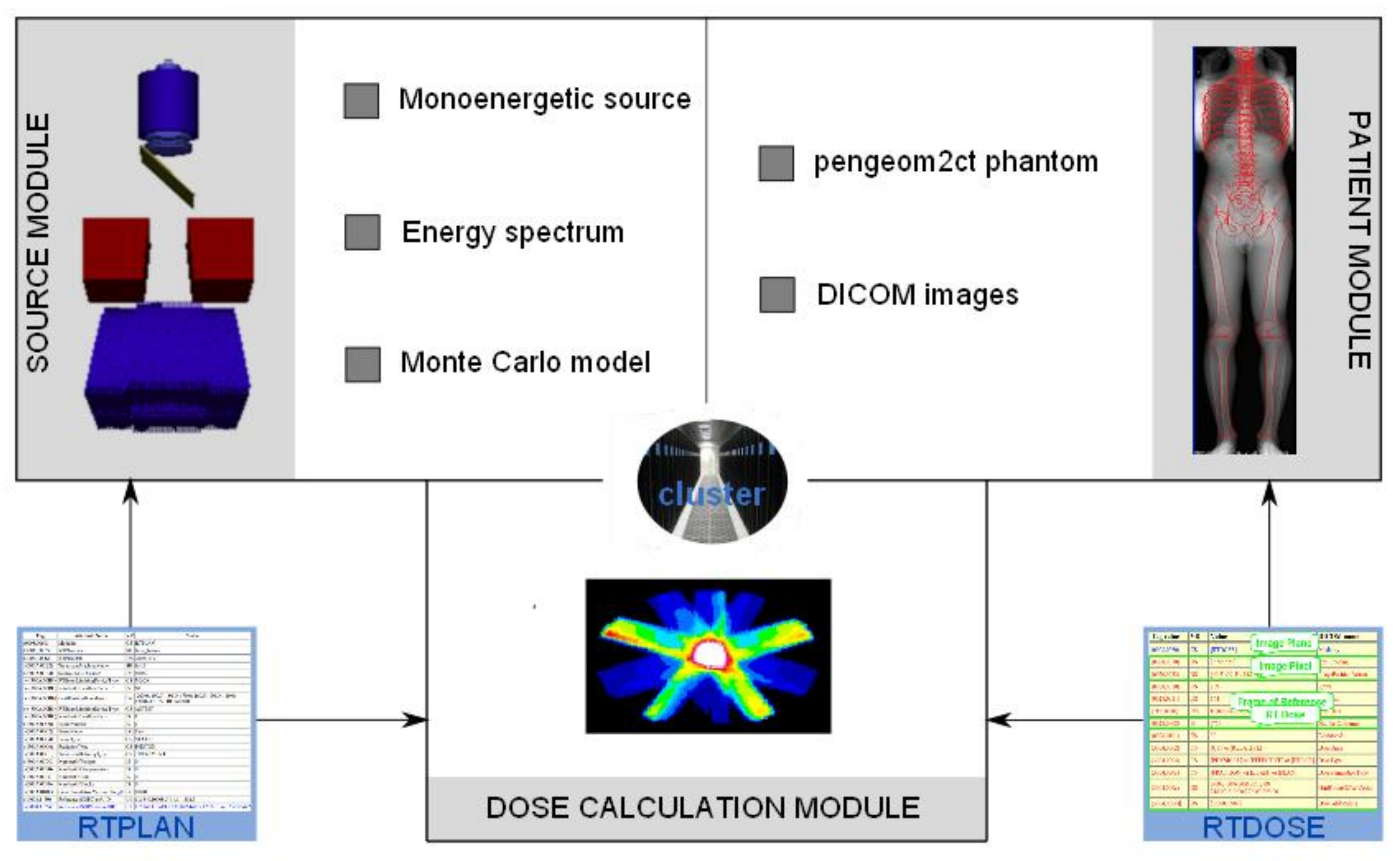
The patient module allows the implementation of complex geometries such as phantoms and patients.

The radiation source module is also based on PENELOPE and allows the simulation of different kinds of radiation sources, going from simple sources, such as monoenergetic beams, to more complex sources like the one resulting from the complete modeling of a linac treatment head, including the multileaf collimator (MLC).

\section{TPS evaluation}

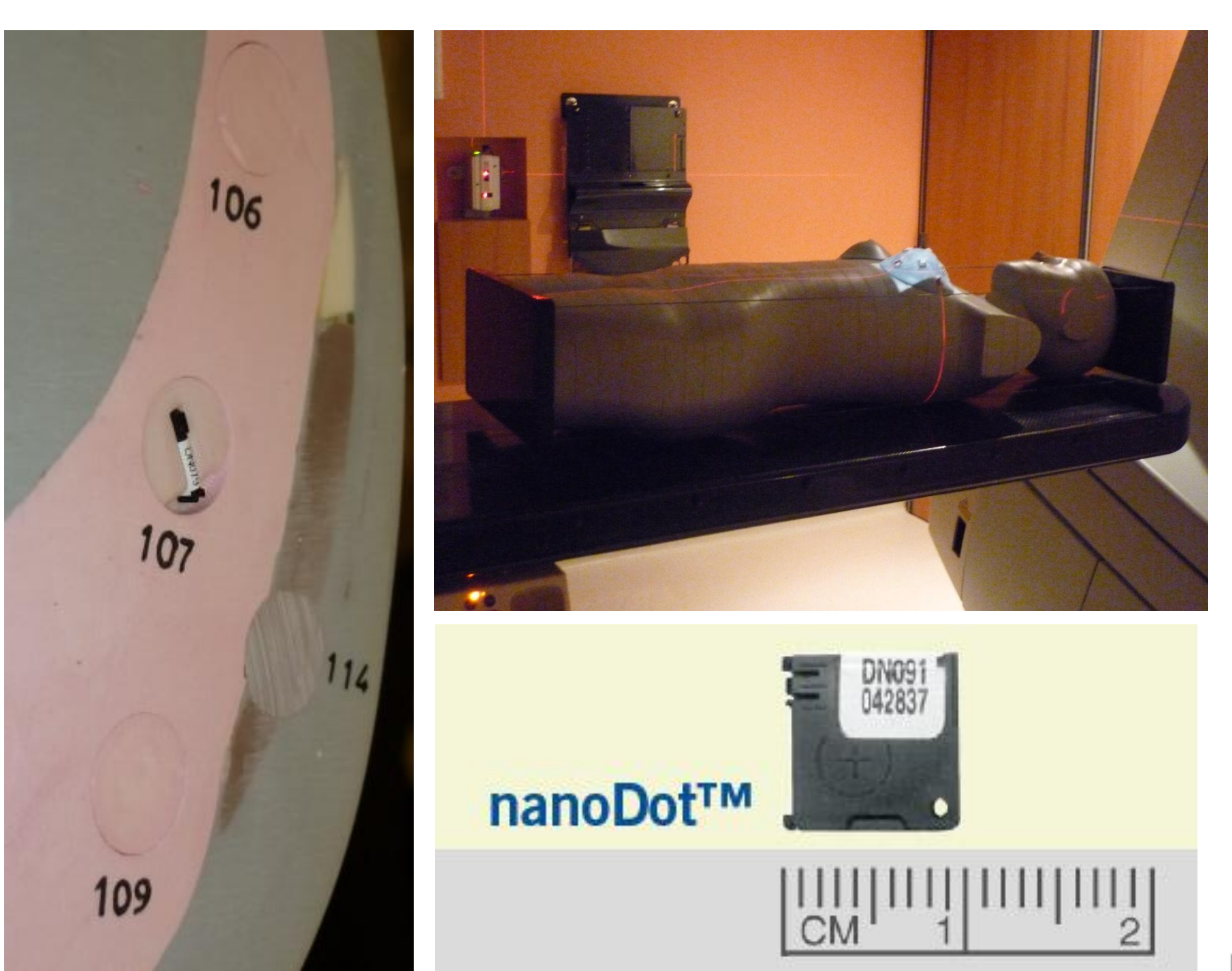

We have determined the limits of the $\mathrm{XiO}$ TPS (CMS - Elekta) by comparing dose distributions obtained with PenSSaRT and the RTDOSE. Comparisons with OSL measurements have also been performed.

\begin{tabular}{ccccccc}
\hline & \multicolumn{3}{c}{ Absorbed dose for the plan (Gy) } & \multicolumn{3}{c}{ Deviation (\%) } \\
& OSL & TPS & PENSSART & OSL vS TPS & OSL vS PENSSART TPS vs PENSSART \\
\hline \multirow{2}{*}{ Lung } & 6.89 & 2.00 & $6.61(3.3 \%)$ & 71.0 & $\mathbf{4 . 1}$ & 69.7 \\
& 3.07 & 2.00 & $3.01(4.4 \%)$ & 34.9 & $\mathbf{2 . 0}$ & 33.6 \\
\hline \multirow{2}{*}{ Bone } & 43.4 & 34.3 & $44.7(1.3 \%)$ & 21.0 & $\mathbf{3 . 0}$ & 23.3 \\
\hline
\end{tabular}

Differences between OSL measurements and PENSSART estimations are of magnitude similar to that of the statistical uncertainties of the MC simulations (about 3\%). On the contrary deviations of TPS calculations from OSL measurements are larger especially in lung and vary from 21 to $71 \%$. We also note that the differences between TPS calculations and PENSSART estimations are close to the differences observed between OSL and TPS values.

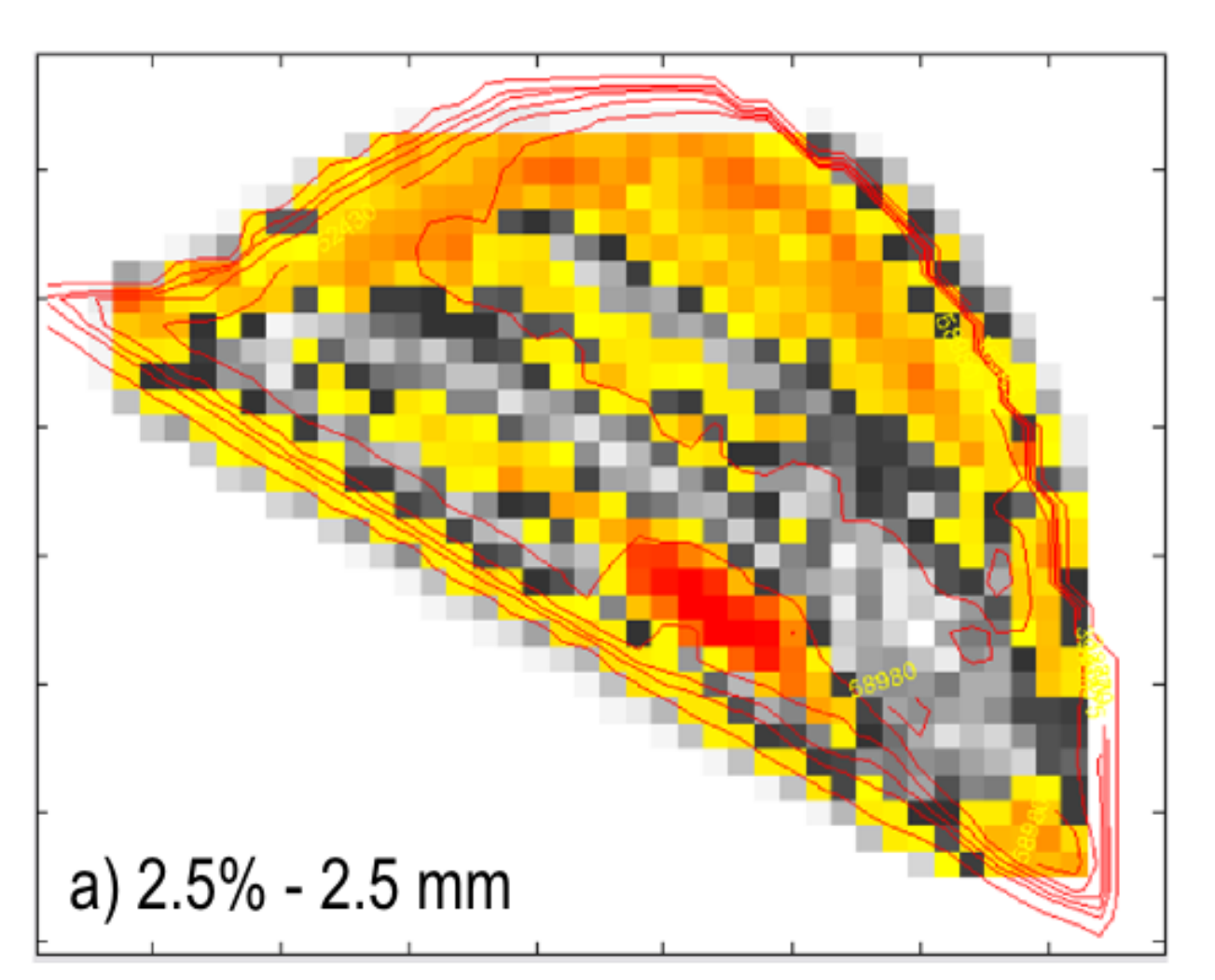

\section{Gamma test}

The reference map is the one obtained with the PENSSART platform. $67.8 \%$ and $91.5 \%$ of pixels pass the test for the $(2.5 \%-2.5 \mathrm{~mm})$ and $(4 \%-4 \mathrm{~mm})$ criteria respectively. The main discrepancies between the two distributions are observed at the lung interface.

\section{Conclusions}

The results showed that the system did not introduce any bias in the dose calculation due to an error in beam settings or in geometry model. Moreover the system also allows determining the limits of a TPS algorithm in the cases of breast and lung treatments. 